\title{
Seasonal dynamics and turnover of microbial phosphorusin a permanent grassland
}

\section{Journal Article}

\section{Author(s):}

Liebisch, Frank; Keller, Felix; Huguenin-Elie, Olivier; Frossard, Emmanuel; Oberson, Astrid; Bünemann, Else K.

Publication date:

2014-04

Permanent link:

https://doi.org/10.3929/ethz-b-000075265

\section{Rights / license:}

In Copyright - Non-Commercial Use Permitted

\section{Originally published in:}

Biology and Fertility of Soils 50(3), https://doi.org/10.1007/s00374-013-0868-5 


\title{
Seasonal dynamics and turnover of microbial phosphorus in a permanent grassland
}

\author{
F. Liebisch • F. Keller • O. Huguenin-Elie • E. Frossard • \\ A. Oberson • E. K. Bünemann
}

Received: 18 July 2013 /Revised: 16 September 2013 / Accepted: 30 September 2013 / Published online: 12 October 2013

(C) Springer-Verlag Berlin Heidelberg 2013

\begin{abstract}
Microbial activity is known to be high under permanent grassland, but consequences for soil phosphorus (P) dynamics and availability are not well understood. Our main objective was to assess the microbial $\mathrm{P}$ turnover derived from the seasonal fluctuations in microbial $\mathrm{P}$ (measured as hexanol-labile $\mathrm{P}\left(\mathrm{P}_{\text {hex }}\right)$ at 13 sampling times during 9 months) in a permanent grassland in Switzerland as affected by different $P$ fertilization treatments ( $P$ inputs of 0 (NK) or $17 \mathrm{~kg} \mathrm{P} \mathrm{ha}^{-1}$ year $^{-1}$ in the form of superphosphate (NPK) or dairy slurry (DS)). Plant P uptake, available inorganic $\mathrm{P}$ measured as resin-extractable $\mathrm{P}\left(\mathrm{P}_{\text {res }}\right)$, potential organic $\mathrm{P}$ mineralization indicated by acid phosphomonoesterase activity and climatic conditions were also recorded. Despite significant differences in plant $P$ uptake and $\mathrm{P}_{\text {res }}(\mathrm{NPK}>\mathrm{DS}>\mathrm{NK})$, the turnover rate of $\mathrm{P}_{\text {hex }}$ was similar in all treatments (approximately once per growing season). Thus, the seasonal $\mathrm{P}$ flux through $\mathrm{P}_{\text {hex }}$ was similar to the stock of $P_{\text {hex }}$, which was about 18,25 and $37 \mathrm{~kg} \mathrm{P} \mathrm{ha}^{-1}$ in NK, NPK and DS, respectively, and larger than the corresponding seasonal plant $P$ uptake of 6,17 and $12 \mathrm{~kg} \mathrm{P} \mathrm{ha}{ }^{-1}$. The estimate of $\mathrm{P}_{\text {hex }}$ turnover based on seasonal dynamics did not confirm previous tracer-based findings of a much faster $\mathrm{P}_{\text {hex }}$ turnover under low availability of inorganic $\mathrm{P}$, and the magnitude of $\mathrm{P}_{\text {hex }}$ turnover
\end{abstract}

Electronic supplementary material The online version of this article (doi:10.1007/s00374-013-0868-5) contains supplementary material, which is available to authorized users.

F. Liebisch · F. Keller · E. Frossard · A. Oberson ·

E. K. Bünemann $(\varangle)$

Institute of Agricultural Sciences, ETH Zurich, Eschikon 33,

CH-8315 Lindau, Switzerland

e-mail: else.buenemann@usys.ethz.ch

O. Huguenin-Elie

Agroscope Reckenholz-Tänikon Research Station (ART),

Reckenholzstrasse 191, CH-8046 Zürich, Switzerland depended on the number of sampling points taken into account. Fluctuations in $\mathrm{P}_{\text {res }}$ and $\mathrm{P}_{\text {hex }}$ were related to soil moisture and indicated competition between plants and microorganisms for available $\mathrm{P}$.

Keywords Phosphorus · Microbial biomass · Turnover · Seasonal fluctuations $\cdot$ Permanent grassland

\section{Introduction}

Soils under grassland typically show higher contents of soil organic matter than arable soils, especially in the absence of ploughing (Whitehead 1995). Accordingly, organic forms of phosphorus $(\mathrm{P})$ are usually more prominent in grassland soils. In 29 temperate grassland soils, on average, $53 \%( \pm 11 \%)$ of total $\mathrm{P}$ was in organic and condensed forms (Turner et al. 2003b), compared to $11 \%( \pm 6 \%)$ in 18 arable soils (Turner et al. 2003a). Likewise, the proportion of total $\mathrm{P}$ held in the microbial biomass is typically greater in permanent grassland than in arable soils (Oberson and Joner 2005). As a result, the microbial processes of organic $\mathrm{P}$ mineralization, $\mathrm{P}$ immobilization into the living microbial biomass and release upon cell death (i.e. remineralization) can be expected to play an important role in $\mathrm{P}$ dynamics of grassland soils, with potential effects on plant $P$ nutrition (Simpson et al. 2012).

These microbial fluxes can be quantified under controlled laboratory conditions, where the use of isotopic dilution techniques permits to derive net organic $\mathrm{P}$ mineralization from the difference of gross $\mathrm{P}$ mineralization and microbial immobilization (Bünemann et al. 2007). Such experiments have been conducted under steady state conditions, i.e. under constant respiration rates and microbial biomass, and have rendered basal gross $\mathrm{P}$ mineralization rates in the order of 1.0 $2.5 \mathrm{mg} \mathrm{P} \mathrm{kg}^{-1} \mathrm{day}^{-1}$ soil for arable and forest soils (Achat et al. 2009; Oehl et al. 2001, 2004). Higher gross P 
mineralization rates of 3.1 and $8.2 \mathrm{mg} \mathrm{P} \mathrm{kg}^{-1}$ day $^{-1}$ have been measured under permanent grassland with and without mineral P fertilization, respectively (Bünemann et al. 2012). The main component of these rates was microbial $\mathrm{P}$ immobilization, which was very fast and extensive, especially under $\mathrm{P}$ limitation.

Complete renewal of the microbial P pool in isotopically $\left({ }^{32} \mathrm{P}{ }^{33}{ }^{33} \mathrm{P}\right)$ labeled soils is reached when the specific activities $\left({ }^{32} \mathrm{P} /{ }^{11} \mathrm{P}\right.$ or $\left.{ }^{33} \mathrm{P} /{ }^{31} \mathrm{P}\right)$ in water-extractable and microbial $\mathrm{P}$ converge (Oberson and Joner 2005), or in other words, when the newly immobilized $\mathrm{P}$ has entirely replaced the $\mathrm{P}$ initially present in the microbial biomass. Such tracer-based estimates of microbial P turnover times at steady state range between 70 and 160 days for the surface horizon of non-amended arable and forest soils (Achat et al. 2010a; Oberson and Joner 2005). In the grassland studied by Bünemann et al. (2012), the tracerderived microbial $\mathrm{P}$ turnover time was about 90 days with $\mathrm{P}$ fertilization, but only 5 days without.

In the field, microbial processes in P cycling are affected by fluctuations in soil moisture and temperature (Blackwell et al. 2010), competition between plants and microorganisms for $P$ (Rousk et al. 2007), interactions between microbial biomass and grazers such as amoebae, protozoa and nematodes (Bloem et al. 1997; Cole et al. 1978), and inputs of organic matter from above- and below-ground plant residues (Chen et al. 2003). As a result, net changes in microbial $P$ throughout the year have been observed. For example, when measured with relatively high temporal resolution (26 sampling points during 2 years) in a grazed pasture in New Zealand, microbial $P$ varied between 80 and $130 \mathrm{mg} \mathrm{P} \mathrm{kg}^{-1}$ soil (Perrott et al. 1990). Fluctuations in microbial $P$ as well as acid phosphomonoesterase activity were positively related to soil moisture and not affected by mineral fertilizer additions. Although fluctuations in microbial $\mathrm{P}$ were smaller (73 to $93 \mathrm{mg} \mathrm{P} \mathrm{kg}{ }^{-1}$ ) at another pasture site in New Zealand with lower $\mathrm{P}$ availability, decreases in microbial $\mathrm{P}$ between sampling points were generally larger than plant $\mathrm{P}$ uptake in unfertilized plots during the corresponding period of time (Perrott et al. 1992). Thus, Perrott et al. (1992) concluded that the $\mathrm{P}$ released from the microbial biomass could potentially account for pasture P uptake during the same period.

Such decreases in microbial biomass can be used to derive an estimate of microbial turnover rate by dividing the sum of losses by the average microbial biomass (McGill et al. 1986). Since this does not capture concurrent growth and death, it is a minimum estimate of microbial turnover which would need to be verified by tracer data. McGill et al. (1986) calculated turnover rates of $0.2-4$ year $^{-1}$ for microbial $C$ in various arable crop rotations in Canada. Similar calculations for arable fields in Germany showed a faster turnover rate for microbial $\mathrm{N}$ $\left(0.9-1.1\right.$ year $\left.^{-1}\right)$ than for microbial C $\left(0.3-1.2\right.$ year $\left.^{-1}\right)$ in three out of four experimental fields (von Lützow and Ottow 1994). For microbial P, the concept was applied to arable soils in
Switzerland, rendering turnover rates between 0.3 and 0.6 year $^{-1}$ (Oberson et al. 1995), and to grassland and forest soils in New Zealand, where faster turnover rates of 0.8 1.3 year $^{-1}$ were found (Chen et al. 2003).

Our main objective was to assess the effect of different fertilization regimes in a permanent grassland on microbial $\mathrm{P}$ turnover derived from the seasonal dynamics of microbial $\mathrm{P}$ (measured as hexanol-labile $\mathrm{P}$ ) during one growing season. We hypothesized that microbial $P$ turnover would be faster in the absence of $P$ fertilization, as previously indicated under laboratory conditions (Bünemann et al. 2012). To reveal a potential competition between plants and microorganisms, we also assessed plant $\mathrm{P}$ uptake, fluctuations in rapidly available inorganic $\mathrm{P}$ (measured as resin-extractable $\mathrm{P}$ ) and acid phosphomonoesterase activity as an indicator of potential organic P mineralization. Climatic conditions (soil and air temperature, precipitation and soil moisture) were monitored to identify the factors underlying the seasonal dynamics of the P pools.

\section{Material and methods}

Experimental site, management and treatments

The two adjacent fertilizer experiments we studied here have a randomized block design and a plot size of $2 \mathrm{~m} \times 5 \mathrm{~m}$ (Fig. 1, supplementary electronic material). They are located near Watt in the Swiss lowland $\left(47^{\circ} 26^{\prime} 44^{\prime \prime} \mathrm{N}, 8^{\circ} 29^{\prime} 32^{\prime \prime} \mathrm{E}, 500 \mathrm{~m}\right.$ above sea level) and were started in 1992 by the Federal Research Station Agroscope Reckenholz-Tänikon (ART) on a permanent grassland (Huguenin-Elie et al. 2006). Annual temperature and precipitation between 1999 and 2009 averaged $9.8^{\circ} \mathrm{C}$ and $1,077 \mathrm{~mm}$, respectively. The mesic grassland grows on a medium-deep $(50-70 \mathrm{~cm})$ Cambisol. Soil texture in the top $10 \mathrm{~cm}$ measured at the beginning of the experiment was 220,340 and $440 \mathrm{~g} \mathrm{~kg}^{-1}$ of clay, silt and sand, respectively (Philipp et al. 2004). The vegetation is an Arrhenatherion elatioris association with about 30 angiosperm species (Liebisch et al. 2013). It is managed at low intensity, with three harvests per year and a late first harvest (after June 15) to preserve plant diversity. In 2009, harvests took place on days of the year 167, 216 and 267.

Three fertilizer treatments were chosen for this study (Table 1). The two mineral fertilized treatments from experiment 1 received $\mathrm{N}$ and $\mathrm{K}(\mathrm{NK})$ or $\mathrm{N}, \mathrm{P}$ and $\mathrm{K}$ (NPK), while the organically fertilized treatment (DS) from experiment 2 received dairy slurry. Mineral $\mathrm{N}$ was applied as ammonium nitrate (split into three applications: at the beginning of the growing season, after the first and after the second harvest), and mineral $\mathrm{P}$ and $\mathrm{K}$ as superphosphate and potassium chloride, respectively (both applied at the beginning of the season, Fig. 1). The 
Fig. 1 Daily air and soil temperature, daily precipitation, experimental management (fertilizer additions in the form of NPK, N only, or dairy slurry (DS)) and harvest and sampling dates. Aboveground temperature and precipitation were measured by a meteorological station in 2$\mathrm{km}$ distance to the field. The soil temperature was measured at the investigated field site (with interruptions due to technical problems)

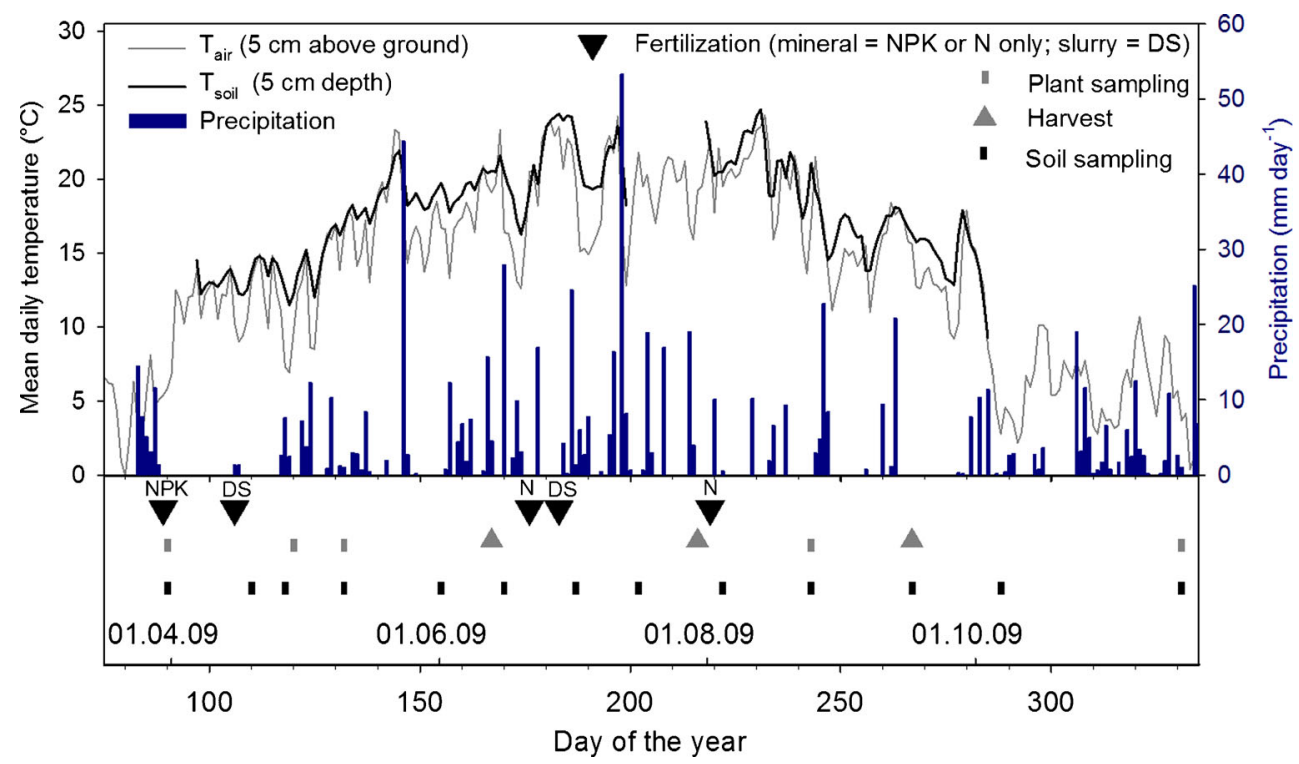

organically fertilized treatment received an annual application of $24 \mathrm{~m}^{3} \mathrm{ha}^{-1}$ dairy slurry, which was split into two equal applications at the beginning of sward growth and after the first harvest. The slurry was diluted with water (1:1) for spreading. Amounts of nutrients applied are shown in Table 1. The number of species and the dominant species were similar in all the treatments (Liebisch et al. 2013).

Table 1 Fertilization type, amounts of annually applied nutrients and selected soil properties (in the top $5 \mathrm{~cm}$ ) in 2009 in the three fertilization treatments NK, NPK and DS in a mesic grassland managed at low intensity since 1992

\begin{tabular}{lllll}
\hline & & $\mathrm{NK}$ & $\mathrm{NPK}$ & $\mathrm{DS}$ \\
\hline $\begin{array}{l}\text { Fertilization } \\
\text { Type }\end{array}$ & & Mineral & Mineral & Dairy slurry \\
$\mathrm{N}$ & $\mathrm{kg} \mathrm{ha}^{-1} \mathrm{year}^{-1}$ & 45 & 45 & $55^{\mathrm{a}}$ \\
$\mathrm{P}$ & $\mathrm{kg} \mathrm{ha}^{-1}$ year $^{-1}$ & 0 & 17 & $17^{\mathrm{a}}$ \\
$\mathrm{K}$ & $\mathrm{kg} \mathrm{ha}^{-1}$ year $^{-1}$ & 83 & 83 & $102^{\mathrm{a}}$ \\
Soil properties & & & & \\
$\mathrm{pH}$ & & $5.2 \pm 0.1$ & $5.4 \pm 0.0$ & $6.8 \pm 0.1$ \\
Total C & $\mathrm{g} \mathrm{kg}^{\mathrm{b}}$ & $24.7 \pm 0.5$ & $24.9 \pm 1.2$ & $29.8 \pm 1.0$ \\
Total $\mathrm{N}^{\mathrm{c}}$ & $\mathrm{g} \mathrm{kg}^{-1}$ & $3.0 \pm 0.1$ & $3.1 \pm 0.2$ & $3.8 \pm 0.1$ \\
Total $\mathrm{P}^{\mathrm{d}}$ & $\mathrm{mg} \mathrm{kg}^{-1}$ & $664 \pm 3.1$ & $784 \pm 12.7$ & $834 \pm 6.4$ \\
Total organic $\mathrm{P}^{\mathrm{e}}$ & $\mathrm{mg} \mathrm{kg}^{-1}$ & $366 \pm 26.0$ & $439 \pm 21.0$ & $480 \pm 5.2$ \\
\hline
\end{tabular}

Means \pm standard deviations $(n=4)$

${ }^{\text {a }}$ Estimated assuming 1:1 dilution of dairy slurry and water according to Flisch et al. (2009)

${ }^{\mathrm{b}}$ Soil $/$ water ratio $=1: 2.5$

${ }^{\mathrm{c}}$ Measured by $\mathrm{CN}$ analyser (Flash EA, Thermo Electron Corporation)

${ }^{\mathrm{d}}$ Extraction with $0.5 \mathrm{M} \mathrm{H}_{2} \mathrm{SO}_{4}$ after incineration

${ }^{\mathrm{e}}$ According to Saunders and Williams (1955)
Climatic data

On site, a data logger (HOBO Micro Station, Onset Computer Corporation, Bourne, MA, USA) was implemented outside the experimental plots to measure the soil temperature $\left(T_{\text {soil }}\right)$ at 5 -cm depth. Additional environmental data (daily precipitation and average air temperature $\left(T_{\text {air }}\right)$ at $5 \mathrm{~cm}$ above the ground) were obtained from the closest meteorological station (Zurich Affoltern, $47^{\circ} 26^{\prime} \mathrm{N}, 8^{\circ} 31^{\prime} \mathrm{E}, 443 \mathrm{~m}$ above sea level, 2$\mathrm{km}$ distance to the field), as available from MeteoSwiss (IDAWEB 2009).

\section{Soil sampling}

The soils were sampled 13 times throughout the season from March to November 2009 (Fig. 1). The sampling period covered a total of 241 days. The sampling dates were chosen to capture the effects of fertilization, harvests and environmental conditions such as dry spells, precipitation events and temperature changes. At each sampling, three randomly distributed soil cores of $2-\mathrm{cm}$ diameter and $5-\mathrm{cm}$ depth were taken in each plot, excluding $0.5 \mathrm{~m}$ from each border, made into one composite sample and stored at $4{ }^{\circ} \mathrm{C}$ in the dark. Within 2 days, the samples were sieved through a 2-mm mesh to remove visible plant material and stones, and gravimetric water content was determined. Extractions for resinextractable and hexanol-labile $\mathrm{P}$ took place within 4 days after sampling. The remaining soil was frozen at $-20{ }^{\circ} \mathrm{C}$ for later determination of acid phosphomonoesterase activity. Soil $\mathrm{pH}$, soil organic $\mathrm{C}$, total $\mathrm{N}$ and total and organic $\mathrm{P}$ were determined on air-dried soil taken on day 243 of the year.

The soil $\mathrm{pH}$ (Table 1) was significantly higher in DS than those in the other two treatments due to a $\mathrm{pH}$ gradient caused by the topography, with the organic fertilizer trial located 
towards the top of a slight slope. The soil organic $\mathrm{C}$ and total $\mathrm{N}$ were also elevated in DS compared to those in NK and NPK, most probably for the same reason, while higher total P in NPK and DS than that in NK was likely to result from P inputs since 1992.

\section{Resin-extractable and hexanol-labile P}

Resin-extractable $\mathrm{P}\left(\mathrm{P}_{\text {res }}\right)$ and hexanol-labile $\mathrm{P}\left(\mathrm{P}_{\text {hex }}\right)$ were determined in duplicates by extraction with anion exchange resin membranes and simultaneous hexanol fumigation (Kouno et al. 1995). In detail, 3-g moist soil was shaken with $30 \mathrm{ml}$ of double-distilled water and two resin strips of $3 \mathrm{~cm} \times$ $2 \mathrm{~cm}$ (BDH Laboratory Supplies \#55164 2S, Poole, England) for $16 \mathrm{~h}$ at $150 \mathrm{rpm}$ on a horizontal shaker, with addition of $1 \mathrm{ml}$ hexanol to fumigated subsamples. The membranes were rinsed with water, and $\mathrm{P}$ was eluted with $0.1 \mathrm{M} \mathrm{NaCl} / \mathrm{HCl}$, followed by colorimetric determination of $\mathrm{P}$ concentrations in the eluates with malachite green (Ohno and Zibilske 1991).

The concentration of $\mathrm{P}$ in non-fumigated subsamples $\left(\mathrm{P}_{\text {res }}\right)$ was subtracted from that in the fumigated subsamples to render $\mathrm{P}_{\text {hex }}$. Hexanol-labile $\mathrm{P}$ was not corrected for incomplete recovery of $\mathrm{P}$ due to sorption, since the mean recovery of a known addition of $\mathrm{P}$ as orthophosphate to a similar set of soil samples taken prior to this experiment was high (93\%) and similar across treatments. We did not apply a conversion factor $(\mathrm{kp})$ either because it varies between soils and methods (Oberson and Joner 2005) and has not been determined for the soil and protocol used in this study. We included a dry standard soil (unfertilized soil from the same site) on each of the 13 extraction dates. Based on the low variation (mean \pm standard deviation) of $\mathrm{P}_{\text {hex }}\left(7.9 \pm 0.9 \mathrm{mg} \mathrm{kg}^{-1}\right)$ and $\mathrm{P}_{\text {res }}(10.1 \pm$ $0.5 \mathrm{mg} \mathrm{kg}^{-1}$ ) in this standard soil, analytical variation between extraction dates was considered to be negligible.

\section{Acid phosphomonoesterase activity}

On eight sampling dates, acid phosphomonoesterase activity was measured in a microplate design following the method of Marx et al. (2001) as modified by Poll et al. (2006). Briefly, $1 \mathrm{~g}$ of frozen soil was dispersed in $100 \mathrm{ml}$ of autoclaved $\mathrm{H}_{2} \mathrm{O}$ using an ultrasonic probe. The suspension was transferred to a microplate with six analytical replicates, 4-methylumbelliferyl phosphate was used as substrate, and the assay was buffered with $0.1 \mathrm{M}$ MES buffer at $\mathrm{pH}$ 6.1. The linear increase in fluorescence was measured at five time points during $180 \mathrm{~min}$ (FLx800, Biotek) and converted into a rate of phosphate release in $\mu \mathrm{mol} \mathrm{g}{ }^{-1} \mathrm{~h}^{-1}$ based on standard curves with additions of 4-methylumbelliferon to each soil. At pH 6.1, the vast majority of the measured activity can be attributed to acid rather than to alkaline phosphomonoesterases (Nannipieri et al. 2011).
Plant sampling and analysis

Plant sampling in all treatments took place at the beginning of the experiment (day 90) and at each of the three harvests (Fig. 1). In NPK only, the plants were also sampled on four additional dates to gain a better resolution of plant growth. The plants were cut at $4 \mathrm{~cm}$ above the ground using electric scissors on a randomly selected area of $0.5 \mathrm{~m} \times 0.5 \mathrm{~m}$ with at least $0.5-\mathrm{m}$ distance to the plot border. The different spots were sampled throughout the year, which limited the possible number of plant samplings.

The plant samples were dried at $60^{\circ} \mathrm{C}$ for 3 days before dry matter determination. The subsamples of the milled plant material from each of the three harvests were analysed for $\mathrm{P}$ concentration by incineration at $550{ }^{\circ} \mathrm{C}$ for $8 \mathrm{~h}$, solubilization of the ashes in $15 \mathrm{M}$ nitric acid and colorimetric $\mathrm{P}$ determination using malachite green.

Calculation of $\mathrm{P}_{\text {hex }}$ turnover rate and flux

The concept of McGill et al. (1986) to estimate the microbial $\mathrm{C}$ turnover from seasonal fluctuations in microbial $\mathrm{C}$ was applied to calculate the turnover rate of $\mathrm{P}_{\text {hex }}$ (Eq. 1):

$\mathrm{P}_{\text {hex }}$ turnover rate $=\frac{\sum \mathrm{P}_{\text {hex }} \text { losses }}{\text { meanP } \mathrm{P}_{\text {hex }}}$,

with the sum of $\mathrm{P}_{\text {hex }}$ losses ( $\sum \mathrm{P}_{\text {hex }}$ losses) calculated from the sum of decreases in $\mathrm{P}_{\text {hex }}$ between two subsequent measurements, and the mean $P_{\text {hex }}$ is defined as the average $\mathrm{P}_{\text {hex }}$ of all the measurement dates, both given in $\mathrm{mg} \mathrm{Pg}^{-1}$ of dry soil. In this study, the $\mathrm{P}_{\text {hex }}$ turnover rate is expressed per season and accounts for the period of 241 days between the first and the last sampling. Accordingly, the $\mathrm{P}_{\text {hex }}$ turnover time (in days) was derived by dividing the turnover rate by the number of days per season (241 days).

The $\mathrm{P}$ flux through the microbial biomass $\left(\mathrm{P}_{\text {hex }}\right.$ flux $)$ was then calculated as shown in Eq. 2:

$P_{\text {hex }}$ flux $=\frac{\text { mean }_{\text {hex }} \times \rho \times D \times \text { area }}{P_{\text {hex }} \text { turnover rate }}$,

where $\rho$ is the bulk density of the topsoil $\left(1.05 \mathrm{~g} \mathrm{~cm}^{-3}\right), D$ is the sampling depth of $5 \mathrm{~cm}$ and the area is $1 \mathrm{ha}$. The resulting numerator of Eq. 2 is the mean $\mathrm{P}_{\text {hex }}$ stock (in $\mathrm{kg} \mathrm{P} \mathrm{ha}^{-1}$ ), and the $\mathrm{P}_{\text {hex }}$ flux for the period of 241 days is thus given in $\mathrm{kg} \mathrm{P} \mathrm{ha}{ }^{-1}$. The mean $\mathrm{P}_{\text {res }}$ stock (in $\mathrm{kg} \mathrm{P} \mathrm{ha}^{-1}$ ) was calculated similar to the mean $\mathrm{P}_{\text {hex }}$ stock.

Statistical analysis

Statistical analyses were performed with $\mathrm{R}$ version 2.8.1 ( $\mathrm{R}$ Development Core Team 2008). Prior to analysis, the percentage data of soil moisture were transformed to their arc sin. 
Treatment and temporal differences within each treatment were analysed by ANOVA. If the $F$ test was significant at $p<0.01$, the least significant difference (LSD) was calculated with an alpha of 0.05 . The Holm adjustment for $p$ values was always applied to control for false positives in multiple comparisons. Correlation coefficients $(\rho)$ and their level of significance were calculated by the Pearson product-moment correlation.

\section{Results}

Climatic conditions

In 2009 , there were 246 vegetation days $\left(T_{\text {air }}>5^{\circ} \mathrm{C}\right)$, with a continuous period between days 85 and 287 (Fig. 1). Longer continuous periods with $T_{\text {air }}$ mostly above $20{ }^{\circ} \mathrm{C}$ were observed between days 179-186 and days 218-240, with daily maxima of 24.4 and $24.8{ }^{\circ} \mathrm{C}$ on days 183 and 231, respectively. The $T_{\text {soil }}$ generally followed $T_{\text {air }}$, but with smaller fluctuations. Precipitation was reasonably well distributed throughout the season, averaging $85 \mathrm{~mm}( \pm 46)$ per month. Only April (days 91120) was exceptionally dry $(15 \mathrm{~mm})$. The changes in soil moisture (Fig. 2) reflected the distribution of precipitation, with similar fluctuations between the treatments. However, DS showed a higher water holding capacity of about $0.5 \mathrm{~g} \mathrm{~g}^{-1}$ compared to $0.45 \mathrm{~g} \mathrm{~g}^{-1}$ in the other two treatments. Soil moisture below $0.2 \mathrm{~g} \mathrm{~g}^{-1}$ was measured on days 155 and 243 by gravimetry. A soil moisture sensor outside the experimental plots additionally registered a period with soil moisture contents below $0.3 \mathrm{~g} \mathrm{~g}^{-1}$ between days 183 and 186 (Fig. 2, supplementary electronic material).

Seasonal dynamics of $\mathrm{P}_{\text {res }}$ and $\mathrm{P}_{\text {hex }}$

The seasonal pattern of fluctuations in $\mathrm{P}_{\text {res }}$ was similar between the treatments, but at different levels (Fig. 2). The values ranged consistently in the order $\mathrm{NPK} \geq \mathrm{DS} \geq \mathrm{NK}$. The amplitude of $\mathrm{P}_{\text {res }}$ was also largest in NPK, with average $\mathrm{P}_{\text {res }}$ varying between $6.5 \mathrm{mg} \mathrm{P} \mathrm{kg}^{-1}$ on day 90 and $17.9 \mathrm{mg} \mathrm{P} \mathrm{kg}^{-1}$ on day 155. Consistent maxima of $\mathrm{P}_{\text {res }}$ were observed at days $110,155,187,243$ and 288 , partly coinciding with dry periods shortly before or at the sampling date.

Fluctuations in $\mathrm{P}_{\text {hex }}$ were not as synchronous between the treatments as for $\mathrm{P}_{\text {res }}$, and the treatments ranged in a different order: $D S \geq N P K \geq N K$ (Fig. 2). The minima of $P_{\text {hex }}$ were observed on days 118, 155 and 267 in DS, on days 90, 118, 187 and 267 in NPK and on days 155 and 243 in NK. Simultaneous increases of $\mathrm{P}_{\text {hex }}$ in the three treatments were observed after days 155 and 267.
Acid phosphomonoesterase activity

Acid phosphomonoesterase activity showed no consistent change in response to the low soil moisture on days 155 and 243 (Fig. 2). In contrast to $\mathrm{P}_{\text {res }}$ and $\mathrm{P}_{\text {hex }}$, the highest acid phosphomonoesterase activities were found in NK and lowest in DS, while NPK was intermediate (except on day 155).

Correlations between soil parameters measured throughout the season

Across all treatments, $\mathrm{P}_{\text {hex }}$ was positively correlated to soil moisture, while the correlation was negative for $\mathrm{P}_{\text {res }}$ (Table 2). Similar and partly significant correlations were found when each treatment was analysed separately. The acid phosphomonoesterase activity was negatively correlated to $\mathrm{P}_{\text {res, }}, \mathrm{P}_{\text {hex }}$ and soil moisture when all the treatments were considered, but these correlations were not significant within single treatments.

Plant biomass and $\mathrm{P}$ uptake

Harvested plant biomass declined from the first harvest to the subsequent ones (Fig. 3). The treatments ranged in the order $\mathrm{NPK} \geq \mathrm{DS} \geq \mathrm{NK}$, with cumulative plant dry matter harvested in 2009 of $7.5,6.2$ and $4.7 \mathrm{tha}^{-1}$, respectively. Total seasonal plant $\mathrm{P}$ uptake reflected the same order of treatments as the biomass, but the differences were even more pronounced (Table 3).

$\mathrm{P}_{\text {hex }}$ turnover rate and flux

The mean seasonal $\mathrm{P}_{\text {hex }}$ ranged in the order $\mathrm{NK}<\mathrm{NPK}<\mathrm{DS}$ (Table 3). In all the treatments, the sum of $\mathrm{P}_{\text {hex }}$ losses was similar to the mean $\mathrm{P}_{\text {hex }}$. Consequently, $\mathrm{P}_{\text {hex }}$ was turned over once during the season, with mean turnover times between 224 and 293 days. The resulting $\mathrm{P}_{\text {hex }}$ flux was lowest in NK (18.1 kg ha ${ }^{-1}$ season $\left.^{-1}\right)$ and highest in DS (36.9 kg P ha ${ }^{-1}$ season ${ }^{-1}$ ). Both $\mathrm{P}_{\text {hex }}$ flux and mean $\mathrm{P}_{\text {hex }}$ stocks were higher than seasonal plant $\mathrm{P}$ uptake, while mean $\mathrm{P}_{\text {res }}$ stocks were lower.

\section{Discussion}

Seasonal dynamics of $\mathrm{P}_{\text {hex }}$ and $\mathrm{P}_{\text {res }}$

In a meta-analysis of seasonal fluctuations in soil microbial $\mathrm{C}$ and N, Wardle (1998) calculated the coefficient of variation (CV) over time in a given treatment as a measure of temporal variability. This allows comparing the extent of seasonal fluctuations between studies, regardless of the use of a correction factor for incomplete extraction of microbial biomass after 
Fig. 2 Gravimetric soil moisture, resin-extractable $\mathrm{P}$, hexanol-labile $\mathrm{P}$ and acid phosphomonoesterase activity in the three fertilizer treatments NK, NPK and DS in 2009. Means \pm standard deviations $(n=4)$. Error bars shown on day 350 indicate least significant difference (LSD test at $\alpha=0.05$, with Holm adjusted $p$ values) for each treatment separately. Vertical dashed grey lines indicate the harvest dates

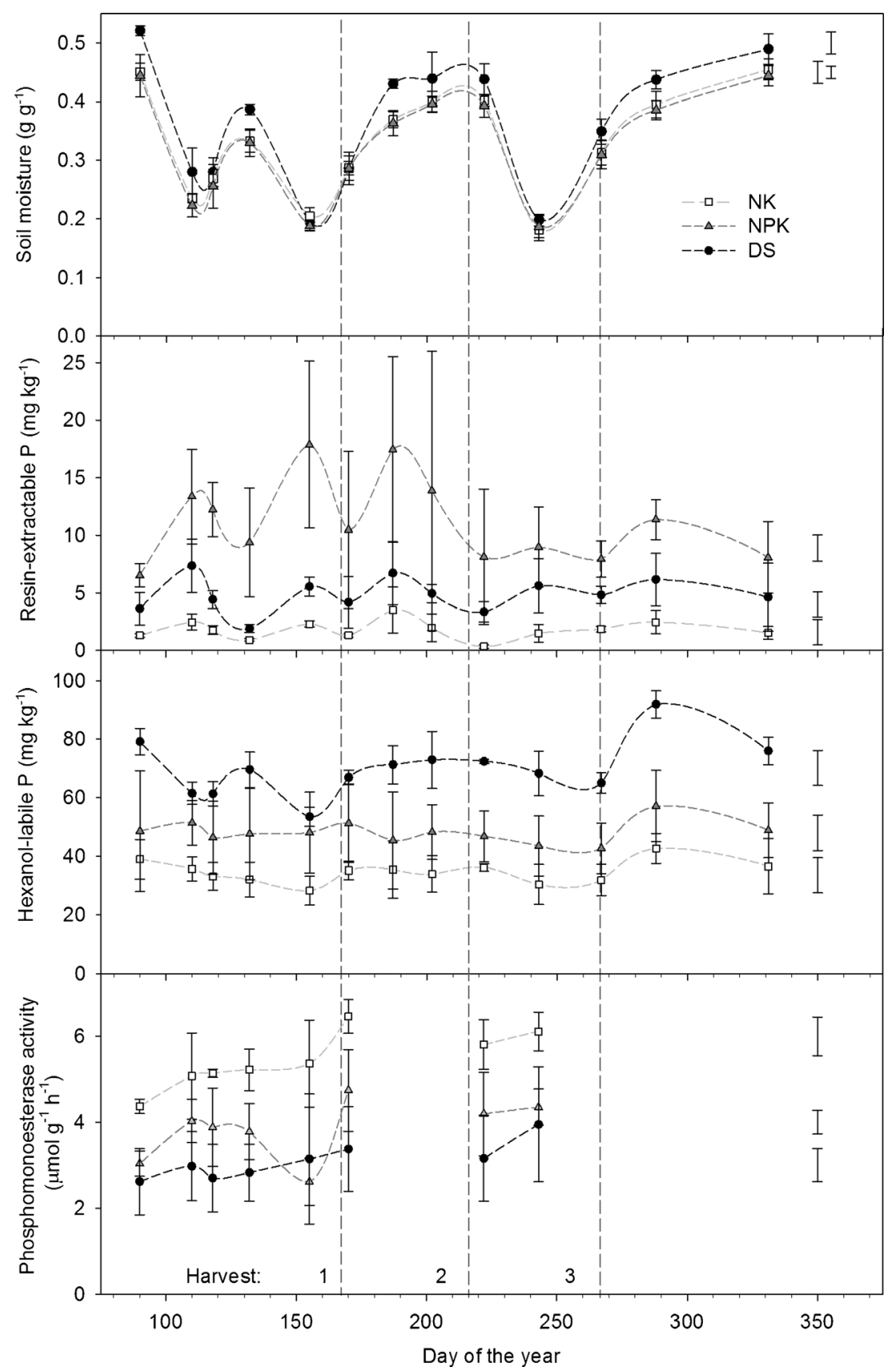

fumigation. Fluctuations in $\mathrm{P}_{\text {hex }}$ in our study (CV 8-13\%) were in the same range as those found for microbial $\mathrm{P}$ by Perrott et al. (1990) in highly productive pastures in New Zealand (CV 10-14 \%) and by He et al. (1997) in fertilized pastures in the UK (CV 13-14\%), while Chen et al. (2003) observed greater temporal variation in microbial P (CV $31 \%)$ in an unfertilized grassland in New Zealand. In all these studies, microbial $\mathrm{P}$ decreased during the periods with relatively low soil moisture content.

A positive relationship between $\mathrm{P}_{\text {hex }}$ and soil moisture content was also observed in our study (Table 2). In a previous paper (Bünemann et al. 2013), we conducted laboratory experiments on the effects of drying and rewetting on $\mathrm{P}$ dynamics, using non-fertilized soil from the same site as in the present study. A significant decrease in $\mathrm{P}_{\text {hex }}$ was observed when soils were dried to gravimetric water contents of $0.10 \mathrm{~g} \mathrm{~g}^{-1}$ or lower, whereas $\mathrm{P}_{\text {hex }}$ remained unchanged between water contents of 0.15 and $0.40 \mathrm{~g} \mathrm{~g}^{-1}$. In the field, however, the lowest observed gravimetric water content was $0.18-0.21 \mathrm{~g} \mathrm{~g}^{-1}$ on days 155 and 243 , and the minima of $P_{\text {hex }}$ were not consistently found on these dates (Fig. 2). Therefore, the observed positive relationship between $\mathrm{P}_{\text {hex }}$ and soil moisture cannot be attributed to drying and rewetting effects but must have other underlying mechanisms such as the 
Table 2 Coefficients of correlation between $\mathrm{P}_{\text {res }}, \mathrm{P}_{\text {hex }}$, acid phosphomonoesterase (PME) activity and soil moisture for the three fertilization treatments NK, NPK and DS alone or together

\begin{tabular}{|c|c|c|c|c|c|}
\hline Treatment & Parameter & $\begin{array}{l}\mathrm{P}_{\text {res }} \\
\mathrm{mg} \mathrm{kg}^{-1}\end{array}$ & $\begin{array}{l}\mathrm{P}_{\text {hex }} \\
\mathrm{mg} \mathrm{kg}^{-1}\end{array}$ & $\begin{array}{l}\text { Acid PME activity } \\
\mu \mathrm{mol} \mathrm{g} \mathrm{g}^{-1} \mathrm{~h}^{-1}\end{array}$ & $\begin{array}{l}\text { Soil moisture } \\
\mathrm{g} \mathrm{g}^{-1}\end{array}$ \\
\hline \multicolumn{6}{|l|}{ All } \\
\hline & $\mathrm{P}_{\text {res }}$ & 1 & & & \\
\hline & $P_{\text {hex }}$ & 0.09 & 1 & & \\
\hline & Acid PME activity & $-0.30^{* *}$ & $-0.60^{* * *}$ & 1 & \\
\hline & Soil moisture & $-0.17^{*}$ & $0.39 * * *$ & $-0.22 *$ & 1 \\
\hline \multicolumn{6}{|l|}{ NK } \\
\hline & $\mathrm{P}_{\text {res }}$ & 1 & & & \\
\hline & $\mathrm{P}_{\text {hex }}$ & -0.12 & 1 & & \\
\hline & Acid PME activity & -0.06 & 0.11 & 1 & \\
\hline & Soil moisture & -0.16 & $0.49 * * *$ & -0.29 & 1 \\
\hline \multicolumn{6}{|l|}{ NPK } \\
\hline & $\mathrm{P}_{\text {res }}$ & 1 & & & \\
\hline & $P_{\text {hex }}$ & -0.10 & 1 & & \\
\hline & Acid PME activity & -0.12 & -0.21 & 1 & \\
\hline & Soil moisture & $-0.29 *$ & 0.18 & -0.06 & 1 \\
\hline \multicolumn{6}{|l|}{ DS } \\
\hline & $\mathrm{P}_{\text {res }}$ & 1 & & & \\
\hline & $P_{\text {hex }}$ & -0.0 & 1 & & \\
\hline & Acid PME activity & 0.31 & 0.17 & 1 & \\
\hline & Soil moisture & -0.20 & $0.68 * * *$ & -0.32 & 1 \\
\hline
\end{tabular}

interaction between plants and microorganisms, which may be affected by changes in quantities and diffusion of root exudates.

Indeed, the large synchronous increase in $\mathrm{P}_{\text {hex }}$ in all fertilization treatments after the third harvest could be caused by belowground $\mathrm{C}$ input by plants from root exudates and root death, which is supported by studies showing increased soil microbial biomass after cutting of grassland plants (Guitian and Bardgett 2000; Mawdsley and Bardgett 1997). This effect was smaller after the first and even absent after the second harvest, which we attribute to the high plant growth rate after these harvests (Fig. 3) and thus a strong competition for available $\mathrm{P}$ between microorganisms and plants. This is corroborated by the fact that $\mathrm{P}_{\text {res }}$ decreased after the first and second harvests, whereas it increased after the third (Fig. 2). Although microorganisms can potentially outcompete plants with respect to P uptake (Rousk et al. 2007), their competitiveness is governed by $\mathrm{C}$ availability which can be regulated by plants (Marschner et al. 2011). In addition, the unidirectional flow of nutrients from the soil to the roots gives plants a competitive advantage over time (Kuzyakov and Xu 2013).

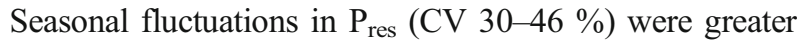
than those in $\mathrm{P}_{\text {hex }}$ and negatively related to soil moisture (Table 2). Under laboratory conditions, $\mathrm{P}_{\text {hex }}$ and $\mathrm{P}_{\text {res }}$ were negatively correlated to soil moisture contents of 0.02 $0.40 \mathrm{~g} \mathrm{~g}^{-1}$, suggesting that the majority of the released $\mathrm{P}$ originated from the microbial biomass, even though abiotic contributions due to aggregate disruption were also identified
Fig. 3 Aboveground (cut above $4 \mathrm{~cm}$ ) biomass (t dry matter ha ${ }^{-1}$ ) in the three fertilizer treatments NK, NPK and DS in 2009, with more frequent sampling in NPK than in NK and DS. Means \pm standard deviations $(n=4)$

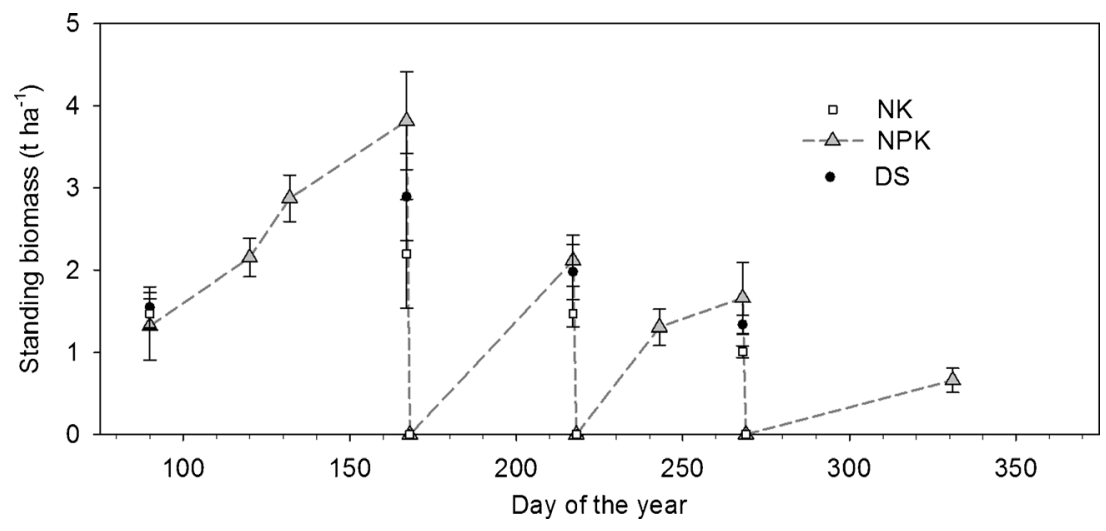


Table 3 Mean seasonal hexanol-labile $\mathrm{P}\left(\mathrm{P}_{\text {hex }}\right)$, calculated $\mathrm{P}_{\text {hex }}$ turnover and fluxes in the top $5 \mathrm{~cm}$ of the soil, and stocks of resin-extractable $\mathrm{P}\left(\mathrm{P}_{\text {res }}\right)$ and $\mathrm{P}_{\text {hex }}$ compared to total seasonal plant $\mathrm{P}$ uptake as affected by the three fertilization treatments NK, NPK and DS

\begin{tabular}{|c|c|c|c|c|c|}
\hline & & NK & NPK & DS & LSD \\
\hline Mean $P_{\text {hex }}$ & $\left(\mathrm{mg} \mathrm{kg}^{-1}\right)$ & $34.6 \pm 4.6$ & $47.8 \pm 9.2$ & $70.0 \pm 1.7$ & 11.4 \\
\hline$\sum$ of $\mathrm{P}_{\text {hex }}$ losses & $\left(\mathrm{mg} \mathrm{kg}^{-1}\right)$ & $34.5 \pm 12.2$ & $52.1 \pm 9.7$ & $70.4 \pm 16.8$ & 21.5 \\
\hline $\mathrm{P}_{\text {hex }}$ turnover rate & $\left(\right.$ season $\left.^{-1}\right)$ & $1.03 \pm 0.43$ & $1.11 \pm 0.24$ & $1.00 \pm 0.23$ & 0.54 \\
\hline $\mathrm{P}_{\text {hex }}$ turnover time & (days) & $293 \pm 194$ & $224 \pm 47$ & $251 \pm 64$ & 212 \\
\hline$P_{\text {hex }}$ flux & $\left(\mathrm{kg} \mathrm{ha}^{-1}\right.$ season $\left.^{-1}\right)$ & $18.1 \pm 6.4$ & $27.4 \pm 5.1$ & $36.9 \pm 8.8$ & 11.3 \\
\hline Mean $P_{\text {res }}$ stock & $\left(\mathrm{kg} \mathrm{ha}^{-1}\right)$ & $0.9 \pm 0.1$ & $5.9 \pm 0.8$ & $2.6 \pm 0.4$ & 1.1 \\
\hline Mean $\mathrm{P}_{\text {hex }}$ stock & $\left(\mathrm{kg} \mathrm{ha}^{-1}\right)$ & $18.2 \pm 2.4$ & $25.1 \pm 4.8$ & $36.7 \pm 0.9$ & 6.0 \\
\hline Total plant $\mathrm{P}$ uptake & $\left(\mathrm{kg} \mathrm{ha}^{-1}\right.$ year $\left.^{-1}\right)$ & $6.2 \pm 1.1$ & $16.6 \pm 1.4$ & $11.7 \pm 1.5$ & 2.7 \\
\hline
\end{tabular}

Means \pm standard deviations $(n=4)$. Least significant differences (LSD) calculated for $\alpha=0.05$, with Holm adjusted $p$ values

(Bünemann et al. 2013). In the field, the absence of a correlation between $\mathrm{P}_{\text {hex }}$ and $\mathrm{P}_{\text {res }}$ (Table 2) points to non-microbial factors governing $P_{\text {res }}$. Magid and Nielsen (1992) suggested that microscale changes in redox status of ferric minerals may affect the extractability of inorganic P. However, such effects were negligible in well-drained soils (Henderson et al. 2012). More importantly, plant $\mathrm{P}$ uptake may be quite sensitive to soil moisture content, which may affect the competition between plants and microorganisms for $\mathrm{P}_{\text {res. }}$. Indeed, Jupp and Newman (1987) observed cessation of $\mathrm{P}$ uptake by Lolium perenne at gravimetric soil water contents below $0.20 \mathrm{~g} \mathrm{~g}^{-1}$, equivalent to soil matric potentials of about $-6,000 \mathrm{hPa}$. In our soil, this corresponds to gravimetric soil water contents of 0.06$0.14 \mathrm{~g} \mathrm{~g}^{-1}$ as determined with a soil water retention curve (Fig. 3, supplementary electronic material). This curve also indicates that a reduction in $\mathrm{P}$ uptake due to limited diffusion could be expected below gravimetric water contents of about $0.30 \mathrm{~g} \mathrm{~g}^{-1}$, equivalent to about $-1,000 \mathrm{hPa}$, since field capacity extends only to $\mathrm{pF} 2.5(=-316 \mathrm{hPa})$. Thus, the transient increases in $\mathrm{P}_{\text {res }}$ on days 110, 155, 187 and 243 could be

Table 4 Effect of sampling frequency on $\mathrm{P}_{\text {hex }}$ turnover rate during the season of 2009

\begin{tabular}{llll}
\hline Scenario & \multicolumn{2}{l}{$\mathrm{P}_{\text {hex }}$ turnover rate $\left(\right.$ season $\left.^{-1}\right)$} \\
\cline { 2 - 4 } & NK & NPK & DS \\
\hline A $(n=12)$ & $0.95 \pm 0.06$ & $1.03 \pm 0.05$ & $0.90 \pm 0.08$ \\
B $(n=9)$ & $0.81 \pm 0.34$ & $0.87 \pm 0.28$ & $0.85 \pm 0.28$ \\
C $(n=5)$ & $0.41 \pm 0.19$ & $0.36 \pm 0.07$ & $0.24 \pm 0.09$
\end{tabular}

Scenario A $(n=12)$ : Turnover rate was calculated based on 12 sampling times, for all 13 possible combinations, i.e. excluding each of the 13 sampling times once. Scenario B $(n=9)$ : One sampling per month (days $90,110,132,155,185,222,267,288$ and 331). Scenario $C(n=5)$ : One sampling every 2 months (days 90, 132, 185, 267 and 331). Means \pm standard deviations of 13 different estimates (A) or of 4 field replicates (B and C) explained by a transient decrease in plant $\mathrm{P}$ uptake during dry periods, whereas the maxima in $\mathrm{P}_{\text {res }}$ on day 288 could be attributed to the very low plant $\mathrm{P}$ uptake after the third harvest as discussed above.

Turnover rate of $\mathrm{P}_{\text {hex }}$

Our hypothesis of faster microbial P turnover in NK was based on our previous tracer-based finding of much faster and greater microbial $\mathrm{P}$ immobilization in the absence than in the presence of $P$ fertilization (Bünemann et al. 2012). However, the turnover of $\mathrm{P}_{\text {hex }}$ calculated from the seasonal dynamics of $P_{\text {hex }}$ was similar in all the three fertilization treatments (Table 3), rendering $\mathrm{P}_{\text {hex }}$ turnover times of 224 293 days, compared to the tracer-based estimates of about 5 and 90 days in NK and NPK, respectively. Thus, it is possible that microbial tracer uptake overestimates $\mathrm{P}_{\text {hex }}$ turnover, especially under $\mathrm{P}$ limitation, when high affinity $\mathrm{P}$ transporters enable microorganisms to take up the tracer very efficiently (Wanner 1996). This would lead to rapid microbial P uptake shortly after soil disturbance due to labeling when the specific activity of the soil solution is still very high and would indicate a lack of continuing exchange between microorganisms and the soil solution afterwards. Based on a modeling study, Achat et al. (2010b) postulated that the microbial P pool may consist of two pools with different turnover times and that the one with a very fast turnover of 5-9 days soon became persistent, retaining the immobilized tracer.

The estimation of the $\mathrm{P}_{\text {hex }}$ turnover rate based on net changes in $\mathrm{P}_{\text {hex }}$ over time is likewise problematic. As pointed out by Harden and Joergensen (2000), it may be affected by the spatial variability of microbial biomass measurements. If this was not eliminated by our sampling scheme, it would have caused an overestimation of the turnover rate. The $\mathrm{P}_{\text {hex }}$ turnover rate may also largely depend on the number and selection of sampling times. To check for the influence of each specific sampling date, we calculated the $\mathrm{P}_{\text {hex }}$ turnover 
rate again based on 12 sampling dates, i.e. leaving out each of the 13 sampling dates once (scenario A, Table 4). This resulted in slightly reduced turnover rates $\left(0.9-1.0\right.$ season $\left.^{-1}\right)$ which were still similar between the treatments. Leaving out the final sampling date with a consistent decrease in $\mathrm{P}_{\text {hex }}$ in all treatments decreased the turnover rates most. Similarly, an increase in sampling dates would have increased the $\mathrm{P}_{\text {hex }}$ turnover rate, especially if we missed major maxima or minima with our current sampling design. Calculating the $\mathrm{P}_{\text {hex }}$ turnover based on gains rather than losses in $\mathrm{P}_{\text {hex }}$ between two sampling times resulted in similar estimates of $\mathrm{P}_{\text {hex }}$ turnover to the values in Table 3 (data not shown). However, reducing the sampling times to one sampling each month (scenario B) or every 2 months (scenario $\mathrm{C}$ ) further reduced the $\mathrm{P}_{\text {hex }}$ turnover rate, especially in scenario $\mathrm{C}$ (Table 4). This agrees with the theoretical considerations of Harden and Joergensen (2000) that microbial turnover will increase with the number of sampling times.

We conclude that microbial $\mathrm{P}$ turnover rates derived from seasonal dynamics can hardly be compared between studies which use different numbers of sampling times. Unfortunately, a direct comparison of the approach by McGill et al. (1986) to radiotracer-based approaches is hampered by problems of applying radioisotopes in the field and by the steady-state assumption in isotopic dilution experiments. An alternative method could be the analysis of the isotopic composition of oxygen in phosphate in different soil $\mathrm{P}$ pools in combination with modeling (Tamburini et al. 2012). In very young soils in a glacier forefield, this approach showed a fast microbial $\mathrm{P}$ turnover time of 20 days to be most likely. A comparison to the McGill approach across different ecosystems would be valuable, especially since the oxygen isotope approach potentially integrates the seasonal dynamics occurring in the field.

Implications for $\mathrm{P}$ availability and plant $\mathrm{P}$ uptake

After 17 years of different $\mathrm{P}$ fertilization regimes, significant differences in available $\mathrm{P}$ had developed in the investigated topsoil layer, with average $\mathrm{P}_{\text {res }}$ of $1.8,4.9$ and $11.2 \mathrm{mg} \mathrm{P} \mathrm{kg}^{-1}$ in NK, DS and NPK, respectively. Analysis of $\mathrm{P}_{\text {res }}$ in deeper soil layers $(5-10 \mathrm{~cm}$ and $10-20 \mathrm{~cm})$ did not reveal significant differences between treatments (data not shown). Therefore, we limit our discussion of $\mathrm{P}$ availability to this topsoil layer. Importantly, P deficiency in NK and DS was indicated by the fact that dry matter yields in NK and DS reached only 63 and $83 \%$ of the yield in NPK (Fig. 3) and that seasonal P uptake in NK and DS was 37 and $70 \%$ of that in NPK (Table 3). Plant N limitation in DS is unlikely based on the finding that plant $\mathrm{N}$ concentrations in DS were similar to those in NPK, while plant $\mathrm{P}$ concentrations were reduced in DS (Liebisch et al. 2013).

At the same time, the mean $\mathrm{P}_{\text {hex }}$ stock was greatest in DS and smallest in $\mathrm{NK}$, and due to the similar $\mathrm{P}_{\text {hex }}$ turnover rate in all the treatments, the $\mathrm{P}_{\text {hex }}$ flux ranged also in the order DS $>$ NPK $>$ NK (Table 3 ). $P_{\text {hex }}$ stock and flux in the topsoil were 1.5-3 times greater than seasonal plant $P$ uptake. However, we cannot deduce an effect of this $\mathrm{P}_{\text {hex }}$ flux on plant $\mathrm{P}$ uptake, which ranged in the same treatment order as $\mathrm{P}_{\text {res }}$ and not as $\mathrm{P}_{\text {hex }}$ flux. Likewise, the greater potential organic $\mathrm{P}$ mineralization indicated by greater acid phosphomonoesterase activity in NK than NPK (Fig. 2) is in accordance with the differences observed in gross and net $\mathrm{P}$ mineralization rates (Bünemann et al. 2012), but did not seem to improve plant $P$ availability in NK. The lower acid phosphomonoesterase activity in NPK may also be attributed to the inhibition of phosphomonoesterase activity by inorganic P (Nannipieri et al. 1978) or to changes in the bacterial community composition, with potential implications for the expression of functional genes such as alkaline phosphatase genes (Tan et al. 2013). The lowest activity in DS may be caused by differences in soil pH (Table 1), with the relative importance of acid vs. alkaline phosphomonoesterase decreasing as $\mathrm{pH}$ increases. Our observations are in contrast to Simpson et al. (2012) who compared two soils with similar inorganic P status and observed greater plant P uptake from the soil which had higher concentrations of organic P, suggesting an important role for soil biological processes in $\mathrm{P}$ nutrition of grasslands.

Finally, the relatively large fluctuations in $\mathrm{P}_{\text {res }}$ illustrate the difficulty to recommend suitable sampling periods to estimate $\mathrm{P}$ availability as a basis for fertilization recommendations. Our data suggest that the maxima of $\mathrm{P}_{\text {res }}$ can be expected when sampling is done during or shortly after dry periods, while minima are likely to occur during periods with high plant $\mathrm{P}$ uptake rates. At least in Central Europe, the best sampling time may be during winter when soils are usually moist, and plant uptake is negligible.

\section{Conclusions}

Different $\mathrm{P}$ fertilization strategies in an extensively managed permanent grassland in Switzerland affected plant $\mathrm{P}$ uptake and $\mathrm{P}_{\text {res}}$, both ranging in the order $\mathrm{NPK}>\mathrm{DS}>\mathrm{NK}$. In contrast, the turnover rate of $\mathrm{P}_{\text {hex }}$ as deduced from the temporal fluctuations in $\mathrm{P}_{\text {hex }}$ was similar in all treatments (approximately once per growing season). The seasonal flux of $\mathrm{P}$ through the microbial biomass was therefore similar to the stock of $\mathrm{P}_{\text {hex }}$, which ranged in the order $\mathrm{DS}>\mathrm{NPK}>\mathrm{NK}$ and was $1.5-3$ times greater than plant $\mathrm{P}$ uptake, even though only the top $5 \mathrm{~cm}$ of the soil was analysed. While the estimation of $\mathrm{P}_{\text {hex }}$ turnover rates based on seasonal dynamics has severe drawbacks, such sampling schemes are still valuable for a better understanding of soil P dynamics. In our study, fluctuations in $\mathrm{P}_{\text {res }}$ and $\mathrm{P}_{\text {hex }}$ pointed to strong interactions between plants and microorganisms, driven by soil moisture and presumably also by alterations in belowground $\mathrm{C}$ inputs following harvests. To 
better understand these interactions between plants, microorganisms and environmental factors, soil $\mathrm{P}$ and $\mathrm{C}$ dynamics as well as plant growth should be studied at greater temporal and spatial resolution.

Acknowledgments We are grateful to Angela Erb for analysing the soil phosphomonoesterase activity. This study was conducted within COST action 869 in a project funded by the Swiss State Secretariat for Education and Research.

\section{References}

Achat DL, Bakker MR, Morel C (2009) Process-based assessment of phosphorus availability in a low phosphorus sorbing forest soil using isotopic dilution methods. Soil Sci Soc Am J 73:2131-2142

Achat DL, Bakker MR, Saur E, Pellerin S, Augusto L, Morel C (2010a) Quantifying gross mineralisation of $\mathrm{P}$ in dead soil organic matter: testing an isotopic dilution method. Geoderma 158:163-172

Achat DL, Morel C, Bakker MR, Augusto L, Pellerin S, Gallet-Budynek A, Gonzalez M (2010b) Assessing turnover of microbial biomass phosphorus: combination of an isotopic dilution method with a mass balance model. Soil Biol Biochem 42:2231-2240

Blackwell MSA, Brookes RC, de la Fuente-Martinez N, Gordon H, Murray PJ, Snars KE, Williams JK, Bol R, Haygarth PM (2010) Phosphorus solubilization and potential transfer to surface waters from the soil microbial biomass following drying-rewetting and freezing-thawing. Adv Agron 106:1-35

Bloem J, de Ruiter P, Bouwman L (1997) Soil food webs and nutrient cycling in agroecosystems. In: van Elsas JD, Trevors JT, Wellington EMH (eds) Modern soil microbiology. Marcel Dekker, New York, pp 245-278

Bünemann EK, Marschner P, McNeill AM, McLaughlin MJ (2007) Measuring rates of gross and net mineralisation of organic phosphorus in soils. Soil Biol Biochem 39:900-913

Bünemann EK, Oberson A, Liebisch F, Keller F, Annaheim KE, Huguenin-Elie O, Frossard E (2012) Rapid microbial phosphorus immobilization dominates gross phosphorus fluxes in a grassland soil with low inorganic phosphorus availability. Soil Biol Biochem 51:84-95

Bünemann EK, Keller B, Hoop D, Jud K, Boivin P, Frossard E (2013) Increased availability of phosphorus after drying and rewetting of a grassland soil: processes and plant use. Plant Soil 370:511-526

Chen CR, Condron LM, Davis MR, Sherlock RR (2003) Seasonal changes in soil phosphorus and associated microbial properties under adjacent grassland and forest in New Zealand. For Ecol Manage 177:539-557

Cole CV, Elliott ET, Hunt HW, Coleman DC (1978) Trophic interactions in soils as they affect energy and nutrient dynamics. V. Phosphorus transformations. Microb Ecol 4:381-387

Flisch R, Sinaj S, Charles R, Richner W (2009) Grundlagen für die düngung im acker- und futterbau. Agrarforschung 16:1-100

Guitian R, Bardgett RD (2000) Plant and soil microbial responses to defoliation in temperate semi-natural grassland. Plant Soil 220:271277

Harden T, Joergensen RG (2000) Relationship between simulated spatial variability and some estimates of microbial biomass turnover. Soil Biol Biochem 32:139-142

He ZL, Wu J, O'Donnell AG, Syers JK (1997) Seasonal responses in microbial biomass carbon, phosphorus and sulphur in soils under pasture. Biol Fert Soils 24:421-428

Henderson R, Kabengi N, Mantripragada N, Cabrera M, Hassan S, Thompson A (2012) Anoxia-induced release of colloid- and nanoparticle-bound phosphorus in grassland soils. Env Sci Techn 46:11727-11734

Huguenin-Elie O, Gago R, Stutz CJ, Lüscher A, Kessler W (2006) Longterm effects of fertilisation on herbage composition, yield and quality of an Arrhenatherion-type meadow. Grassl Sci Eur 11: 550-552. $\mathrm{http}: / /$ www.europeangrassland.org/printed-matter/proceedings.html

IDAWEB (2009) Meteo Swiss, the Swiss Federal Office of Meteorology and Climatology. http://www.meteoschweiz.admin.ch. Accessed 16 Mar 2010

Jupp AP, Newman EI (1987) Phosphorus uptake from soil by Lolium perenne during and after severe drought. J Appl Ecol 24:979-990

Kouno K, Tuchiya Y, Ando T (1995) Measurement of soil microbial biomass phosphorus by an anion exchange membrane method. Soil Biol Biochem 27:1353-1357

Kuzyakov Y, Xu X (2013) Competition between roots and microorganisms for nitrogen: mechanisms and ecological relevance. New Phytol 198:656-669

Liebisch F, Bunemann EK, Huguenin-Elie O, Jeangros B, Frossard E, Oberson A (2013) Plant phosphorus nutrition indicators evaluated in agricultural grasslands managed at different intensities. Eur J Agron 44:67-77

Magid J, Nielsen NE (1992) Seasonal variation in organic and inorganic phosphorus fractions of temperate climate sandy soils. Plant Soil 144:155-165

Marschner P, Crowley D, Rengel Z (2011) Rhizosphere interactions between microorganisms and plants govern iron and phosphorus acquisition along the root axis - model and research methods. Soil Biol Biochem 43:883-894

Marx MC, Wood M, Jarvis SC (2001) A microplate fluorimetric assay for the study of enzyme diversity in soils. Soil Biol Biochem 33:1633-1640

Mawdsley JL, Bardgett RD (1997) Continuous defoliation of perennial ryegrass (Lolium perenne) and white clover (Trifolium repens) and associated changes in the composition and activity of the microbial population of an upland grassland soil. Biol Fert Soils 24:52-58

McGill WB, Cannon KR, Robertson JA, Cook FD (1986) Dynamics of soil microbial biomass and water-soluble organic $\mathrm{C}$ in Breton $\mathrm{L}$ after 50 years of cropping to two rotations. Can J Soil Sci 66:1-19

Nannipieri P, Johnson RL, Paul EA (1978) Criteria for measurement of microbial growth and activity in soil. Soil Biol Biochem 10:223229

Nannipieri P, Giagnoni L, Landi L, Renella G (2011) Role of phosphatase enzymes in soil. In: Bünemann EK, Oberson A, Frossard E (eds) Phosphorus in action - biological processes in soil phosphorus cycling. Springer, Heidelberg, pp 215-243

Oberson A, Joner EJ (2005) Microbial turnover of phosphorus in soil. In: Turner BL, Frossard E, Baldwin D (eds) Organic phosphorus in the environment. CABI, Wallingford, pp 133-164

Oberson A, Besson J-M, Maire N, Sticher H (1995) The role of microbiological processes in soil organic phosphorus transformations in conventional and biological farming systems. In: Mäder P, Raupp J (Eds) Effects of low and high external input agriculture on soil microbial biomass and activities in view of sustainable agriculture. Proceedings of the second meeting in Oberwil (Switzerland), Sep 15-16, 1995. Research Institute of Organic Agriculture (Oberwil) and Institute for Biodynamic Research (Darmstadt), pp 13-23

Oehl F, Oberson A, Sinaj S, Frossard E (2001) Organic phosphorus mineralization studies using isotopic dilution techniques. Soil Sci Soc Am J 65:780-787

Oehl F, Frossard E, Fliessbach A, Dubois D, Oberson A (2004) Basal organic phosphorus mineralization in soils under different farming systems. Soil Biol Biochem 36:667-675

Ohno R, Zibilske LM (1991) Determination of low concentrations of phosphorus in soil extracts using malachite green. Soil Sci Soc Am J 55:892-895

Perrott KW, Sarathchandra SU, Waller JE (1990) Seasonal storage and release of phosphorus and potassium by organic matter and the 
microbial biomass in a high-producing pastoral soil. Aus J Soil Res 28:593-608

Perrott KW, Sarathchandra SU, Dow BW (1992) Seasonal and fertilizer effects on the organic cycle and microbial biomass in a hill country soil under pasture. Aus J Soil Res 30:383-394

Philipp A, Huguenin-Elie O, Flisch R, Gago R, Stutz C, Kessler W (2004) Einfluss der phosphordüngung auf eine fromentalwiese. Agrarforschung 11:86-91

Poll C, Ingwersen J, Stemmer M, Gerzabek MH, Kandeler E (2006) Mechanisms of solute transport affect small-scale abundance and function of soil microorganisms in the detritusphere. Eur J Soil Sci 57:583-595

R Development Core Team (2008) R: a language and environment for statistical computing. R Foundation for Statistical Computing, Vienna, Austria ISBN 3-900051-07-0. http://www.Rproject.org.

Rousk J, Bååth E, Göransson H, Fransson AM (2007) Assessing plantmicrobial competition for P-33 using uptake into phospholipids. Appl Soil Ecol 36:233-237

Saunders WMH, Williams EG (1955) Observations on the determination of total organic phosphorus in soils. J Soil Sci 6:254-267

Simpson M, McLenaghen RD, Chirino-Valle I, Condron LM (2012) Effects of long-term grassland management on the chemical nature and bioavailability of soil phosphorus. Biol Fert Soils 48:607-611
Tamburini F, Pfahler V, Bünemann EK, Gülland K, Bernasconi SM, Frossard E (2012) Oxygen isotopes unravel the role of microorganisms in phosphate cycling in soils. Env Sci Techn 46:5956-5962

Tan H, Barret M, Mooij MJ, Rice O, Morrissey JP, Dobson A, Griffiths B, O'Gara F (2013) Long-term phosphorus fertilisation increased the diversity of the total bacterial community and the $p h o D$ phosphorus mineraliser group in pasture soils. Biol Fert Soils 49:661-672

Turner BL, Cade-Menum BJ, Westermann DT (2003a) Organic phosphorus composition and potential bioavailability in semi-arid arable soils of the western United States. Soil Sci Soc Am J 67:1168-1179

Turner BL, Mahieu N, Condron LM (2003b) The phosphorus composition of temperate pasture soils determined by $\mathrm{NaOH}-\mathrm{EDTA}$ extraction and solution ${ }^{31}$ P NMR spectroscopy. Org Geochem 34:1199-1210

von Lützow M, Ottow JCG (1994) Effect of conventional and biological farming on microbial biomass and its nitrogen turnover in agriculturally used luvisols of the Friedberg plains. J Plant Nutr Soil Sci 157:359-367

Wanner BL (1996) Phosphorus assimilation and control of the phosphate regulon. In: Neidhardt FC (ed) Escherichia coli and Salmonellacellular and molecular biology. ASM Press, Washington, pp 13571381

Wardle DA (1998) Controls of temporal variability of the soil microbial biomass: a global-scale synthesis. Soil Biol Biochem 30:1627-1637

Whitehead DC (1995) Grassland nitrogen. CAB International, Wallingford 